\title{
Inbaltsüberfį̣t
}

\author{
jum exfien Bande.
}

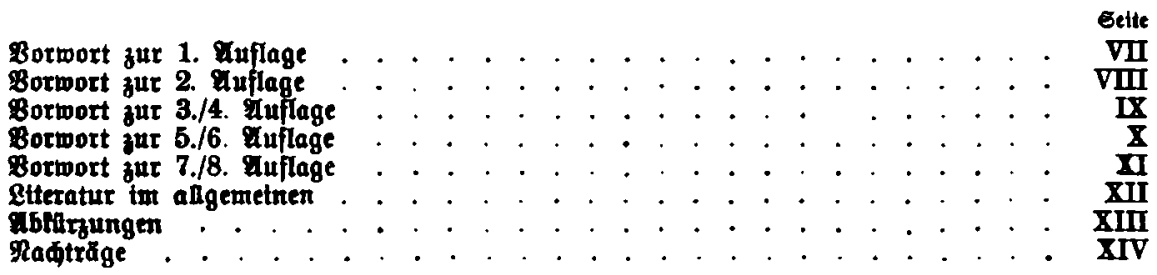

Ciuleitung

I. Bur Borgeididite be $B(5 B$.

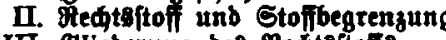

III. Blieberung bes Fethtsitofis

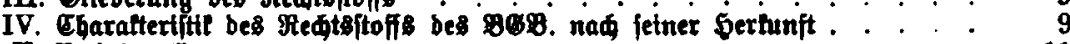

V. Fedt quellen . . . . . . . . . . . . . . 11

VI. Redtsantwenbung , . . , . . . . . . . . . . . . . 17

VII. Otaterialien zum $\mathbf{8 0 9}$. . . . . . . . . . . . . . . 37

VIII. Pibliographte bes $\$$

Eritę $\mathfrak{B u d}$.

\section{Xllgemeinex aeth.}

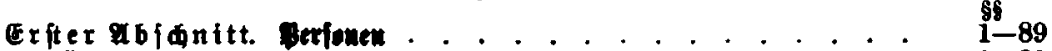

Erfter El tel: Matirlide Serionen . . . . . . . . . 1-20

Bueiter Tttel: Jurtiftide \$erjonen . . . . . . . . . . 21-89

I. Bereine

1. Algemetne Boridutten , . . . . . . . . . 21-64

2. Etrgetragene Beretre
II. Etifturgen

$80-88 \quad 300$

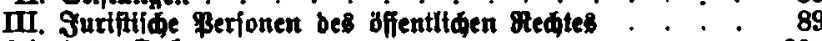

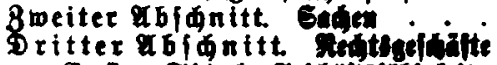

90-103

104-185

Erfter Ittel: Geimaftsfabiglett

104-115 406

Bwetter Eite I: Bitlensertarang

$116-144$

Dritter Ettel: Dettag.

$145-157$

Bterter Fttel: Bebingung. Bettbeftimung . . . . . 158-163

Fitnfter Titel: Bertretung. Bollmadt . . . . . . . . . 164-181

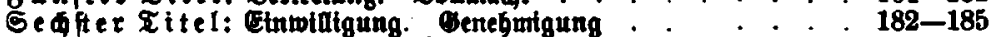

Bierter abífitt. Grifter. Termine . . . . . . . . 186-193

Finfter abjontt. Dertlywang

Eeite

41

41

149

170

329

395

385

434

555

588

611

668

677

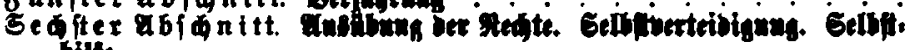

bille . . . . . . . . . . . . . . . 226-231

685

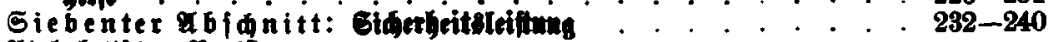

761

768

Xiphabetifines Megifter 
